\title{
Prevalence of upper respiratory tract infections at a tertiary care hospital in the city of São Paulo
}

\author{
Prevalência das infecções de vias aéreas superiores em um hospital terciário na cidade de São Paulo
}

\author{
Amilton Mouro ${ }^{1}$, Luci Black Tabacow Hidal ${ }^{2}$, Marines Dalla Valle Martino ${ }^{3}$, Jacyr Pasternark ${ }^{4}$
}

\begin{abstract}
Objective: To evaluate the prevalence of pathogens in the upper respiratory tract according to age at a tertiary care hospital in the city of São Paulo. Methods: A total of 6,144 biological material tests from upper respiratory airways were analyzed: 740 bacterial cultures, 726 virus screenings and 4,678 rapid tests for S. pyogenes. Results: The most frequently found etiological agent was respiratory syncytial virus $(29.6 \% ; 215 / 726)$. The main agents detected per age groups were: respiratory syncytial virus $(25.34 \%$; $184 / 726)$ in patients aged 28 days-3 years; $S$. pyogenes $(9.5 \%$; $70 / 740$ ) in 3-12 year-old children; influenza virus (8.8\%; 64/726) in adults (18-59 years). Conclusions: The etiologic agents of upper respiratory infections vary according to age and imply diverse clinical and therapeutic management.
\end{abstract}

Keywords: Respiratory tract infections/pathology; Respiratory syncytial viruses; Streptococcus pyogenes

\section{RESUMO}

Objetivo: Avaliar a prevalência de patógenos das vias aéreas superiores em relação à faixa etária de pacientes atendidos em um hospital terciário da cidade de São Paulo. Métodos: Foram analisados 6.144 exames de materiais biológicos provenientes das vias aéreas superiores, sendo 740 de cultura bacteriana, 726 de triagem de vírus e 4.678 provas rápidas para $S$. pyogenes. Resultados: 0 agente etiológico com maior frequência nas infecções de vias aérea superiores foi o vírus sincicial respiratório, com 29,6\% (215/726). Os principais agentes detectados por faixa etária foram: vírus sincicial respiratório em 25,34\% (184/726) dos exames de pacientes com faixa etária entre 28 dias a 3 anos; $S$. pyogenes, com 9,5\% (70/740) na fase da infância (3 a 12 anos); vírus influenza, com 8,8\% (64/726) detectados na fase adulta (18 a 59 anos). Conclusões: 0s agentes etiológicos das infecções de vias aéreas superiores variam de acordo com a faixa etária do paciente, o que resulta em uma conduta clínica e laboratorial diferenciada.
Descritores: Infecções respiratórias/patologia; Vírus sinciciais respiratórios; Streptococcus pyogenes

\section{INTRODUCTION}

The upper respiratory tract infections (URI) are commonly observed in daily practice and it is essential to differentiate viral and bacterial pictures to establish a satisfactory treatment. The frequent use of antibiotics and the easy dissemination of bacterial agents that cause upper airway infections predispose to antimicrobial resistance depending on the microorganism and the antibiotic evaluated ${ }^{(1)}$.

The acute viral respiratory infections account for approximately $75 \%$ of the cases, and the influenza virus and respiratory syncytial virus are the main causal agents. Other agents include the viruses influenza types A and B, parainfluenza 1, 2 and 3, Epstein-Barr, enterovirus and herpes simplex ${ }^{(2)}$. The acute bacterial respiratory infection is mainly caused by Streptococcus pyogenes (S. pyogenes), followed by $H$. influenzae, $S$. aureus and $M$. catarrhalis, and patients present a whitish or purulent exudate, located on the crypts and surface of the tonsils ${ }^{(2)}$.

Some tests can be used for fast diagnosis of $S$. pyogenes, with sensitivity of over $90 \%$ and specificity of $90 \%$; however, despite the high cost, they are easy to perform and have good reproducibility ${ }^{(3)}$.

One important aspect to establish if the acute respiratory infection is viral or bacterial is the age of the patients. In children aged under 3 years, the infection is often not streptococcal; this etiology is more frequent in the 5-17 year-old group. The typical manifestations include fever, no clinical response to penicillin, intense

\footnotetext{
Study carried out at Quality Laboratory of Hospital Israelita Albert Einstein - HIAE, São Paulo (SP), Brazil.

'Master's degree student at Universidade Federal de São Paulo - UNIFESP; Biomedical professional; Quality Laboratory Analyst of Hospital Israelita Albert Einstein - HIAE, São Paulo (SP), Brazil.

${ }^{2} \mathrm{MD}$ at Hospital Israelita Albert Einstein -HIAE, São Paulo (SP), Brazil.

${ }^{3} \mathrm{MD}$ at Hospital Israelita Albert Einstein - HIAE, São Paulo (SP), Brazil.

${ }^{4} \mathrm{MD}$; Infectious disease specialist; Head of the Nosocomial Infection Control Committee of Hospital Israelita Albert Einstein - HIAE, São Paulo (SP), Brazil.

Corresponding author: Amilton Mouro - Avenida Albert Einstein, 627 - Morumbi - CEP 05651-901 - São Paulo (SP), Brazil - Tel.: (11) 3747-2531 - e-mail: amiltonm@einstein.br

Received on May 25, 2009 - Accepted on Jan 19, 2010
} 
exudate on tonsils and negative culture for group A streptococcus $^{(4-5)}$.

The studies on upper respiratory tract infections are important in hospital and in community settings due to their incidence all over the world. Few studies have associated bacterial and viral infections, hindering the relation of the agents and their epidemiology.

The diagnosis of URI is crucial for an effective treatment of patients and, in this context, microbiological investigation by specific exams is an important procedure, together with clinical analysis.

\section{OBJECTIVE}

The purpose of this study was to evaluate the prevalence of upper airway pathogens per age in a group of patients seen at a tertiary care hospital in the city of São Paulo.

\section{METHODS}

The study was carried out at Hospital Israelita Albert Einstein.

A total of 6,144 upper respiratory tract exams performed by a laboratory interface system that provided information to the study database - were included in the investigation. It was a retrospective study, from April to July, in 2006, 2007 and 2008. The exams performed in these periods addressed a heterogeneous population of wide age range with suspected acute respiratory infection of community or hospital origin. The viral screening results were obtained from distinct clinical samples of aerobic culture and rapid test.

\section{Aerobic culture}

The clinical samples were collected with a sterile swab and transported using the Amies medium with charcoal (Swab Copan Amies with charcoal - California, USA) to keep the sample stable for a prolonged period. The samples were plated on blood and chocolate agar and incubated under capnophilic conditions, overnight, at $35^{\circ} \mathrm{C}$. Latex agglutination test was conducted for Streptococcus spp. (Streptococcal grouping kit - Oxoid Ltd., Cambridge, United Kingdom) in suggestive colonies of $S$. pyogenes.

\section{Rapid test}

The clinical samples were collected with sterile swab and transported in dry tube, to which extraction reagents were added. It uses immune assay technology to detect group A streptococcus antigen, according to the manufacturer's instructions (Quickvue Strep A test - Quidel, California, USA).

\section{Virus screening}

The clinical samples were collected with a sterile swab and transported in tube with saline solution. The tubes were centrifuged, forming a cell pellet, and the material was fixed in slides for direct immunofluorescence. The technique enables detecting the viruses influenza $\mathrm{A}$ and $\mathrm{B}$, parainfluenza 1, 2 and 3, adenovirus and respiratory syncytial virus, according to the manufacturer's instructions (Light Diagnostics ${ }^{\mathrm{TM}}$ Simulfluor ${ }^{\circledR}$ Respiratory Screen and Panel Chemicon, Canada) ${ }^{(6)}$.

The study was submitted to and approved by the Research Ethics Committee of the Hospital Israelita Albert Einstein, under protocol no 08/864.

\section{Statistical analysis}

The association of categorical variables with the response variable was evaluated by bivariate analysis using the $\chi^{2}$ test (or Fisher's exact test when $20 \%$ presented values lower than 5).

The mean differences of continuous variables among the groups were assessed by the Student's $t$-test or Mann-Whitney test. Statistical significance level was $0.05(5 \%)$.

\section{RESULTS}

A total of 6,144 upper airway biological material exams were evaluated; in that, 740 were bacterial cultures, 726 virus screenings and 4,678 rapid tests for $S$. pyogenes.

The most frequently found etiological agent in URI was respiratory syncytial virus (RSV) $(29.6 \%$; 215/726), followed by influenza virus $(16 \% ; 116 / 726)$ and $S$. pyogenes $(14.7 \% ; 109 / 740)$.

The main agents detected by age group were RSV, in $25.34 \%(184 / 726)$ of the patients aged 28 days-3 years; $S$. pyogenes, with $9.5 \%(70 / 740)$ in 3-12 year-old children; influenza virus, with $8.8 \%(64 / 726)$ in adults (18-59 years), as shown in figure 1.

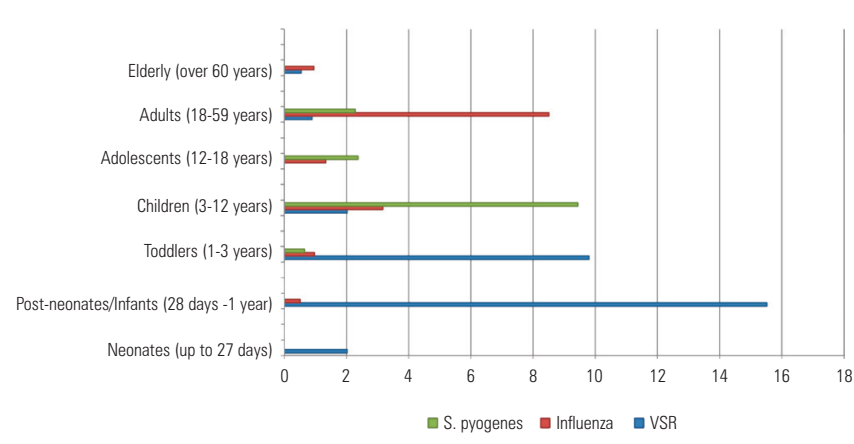

Figure 1. Percentage of bacterial and viral pathogens distributed by age group in the period April-July, 2006 to 2008 
Analyzing the study periods, the frequency of RSV (10 to $30 \%$ ) was more relevant than that of influenza virus. There was greater association with influenza virus in regard to mean temperature and respiratory pathogens, as displayed in figure 2.

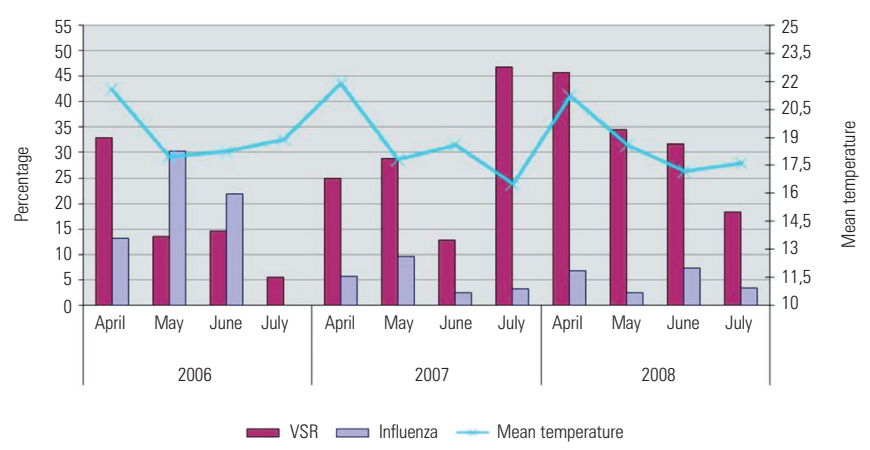

Figure 2. Comparison between influenza virus and respiratory syncytial virus associated to mean temperature in the three periods

The rapid test for $S$. pyogenes, as compared to aerobic culture (gold standard), presented sensibility of $86 \%$ and specificity of $95 \%$ in all periods (Quickvue Strep A test - Quidel, California, USA) (Table 1).

Table 1. Comparison between the specificity and sensibility of rapid antigen test (Quickvue Strep A test - Quidel, California, USA)

\begin{tabular}{lccc}
\hline & $\mathbf{2 0 0 6}(\boldsymbol{\%})$ & $\mathbf{2 0 0 7}(\boldsymbol{\%})$ & $\mathbf{2 0 0 8}(\boldsymbol{\%})$ \\
\hline Sensibility & 90 & 97 & 71 \\
Especificity & 91 & 94 & 100 \\
\hline
\end{tabular}

\section{DISCUSSION}

This study analyzed the main etiologic agents of acute respiratory infection, which are an important aspect to be considered for a satisfactory outcome of the clinical picture. There are few studies in the literature relating a heterogeneous population with viral and bacterial etiology. However, several studies associate these infections in a restrict manner, not favoring a full understanding of the epidemiology of these infections.

Data of exams performed in only four months were collected, considering a short period to analyze seasonality of infections, as already described in the literature ${ }^{(7-8)}$.

The most frequent pathogen was RSV due to the period of study, with a seasonal peak of the virus in São Paulo. The most affected patients by these viruses are in the age group up to 3 years old, as reported in the present study. The infection may lead to complications, such as bronchiolitis and pneumonia ${ }^{(6)}$.
Influenza virus ranked second among the analyzed exams and was the most prevalent agent in adults. According to previous studies, influenza had less positive tests due to restricted collection periods, which did not cover the complete period of higher prevalence of this virus in the city of São Paulo ${ }^{(6)}$. There was also a low prevalence among the elderly, probably due to vaccination campaigns conducted in the country.

S. pyogenes was detected primarily in children (3 to 12 years), prevailing the bacterial profile. It is extremely important to establish the appropriate therapy to decrease the risks of complications, particularly rheumatic fever ${ }^{(9)}$.

The sensibility and specificity values in the three periods are consistent with the literature; nonetheless, in some cases, culture is required to confirm the result.

\section{CONCLUSIONS}

The etiologic agent of upper respiratory tract infections varies according to the age group of patients. This must be considered for appropriate laboratory evaluation and clinical management, which must be aligned for a better outcome. Sensibility and specificity of rapid antigen test to detect $S$. pyogenes showed satisfactory results in the analyzed periods in the study.

\section{REFERENCES}

1. Laupland KB, Ross T, Church DL, Gregson DB. Population-based surveillance of invasive pyogenic streptococcal infection in a large Canadian region. Clin Microbiol Infect. 2006;12(3):224-30.

2. Salomão R, Pignatari ACC. Guias de medicina ambulatorial e hospitalar: infectologia. São Paulo: Manole; 2004.

3. Paes O, Pignatari AC, Weckx LLM, Pignatari SN. Detection of BHSGA by using three different methods: culture, rapid test and molecular biology assay [abstract]. Otolaryngol Head Neck Surg. 2002;127(2):248.

4. Santos AGP, Berezin EN. Comparação entre métodos clínicos e laboratoriais no diagnóstico das faringotonsilites estreptocócicas. J Pediatr (Rio J.). 2005;81(1):23-8.

5. Torres AM, Peterson KE, de Souza AC, Orav EJ, Hughes M, Chen LC. Association of diarrhoea and upper respiratory infections with weight and height gains in Bangladeshi children aged 5 to 11 years. Bull World Health Organ. 2000;78(11):1316-23.

6. Bellei N, Carraro E, Perosa A, Granato C. Patterns of influenza infections among different risk groups in Brazil. Braz J Infect Dis. 2007;11(4):399-402.

7. Wong DM, Blumberg DA, Lowe LG. Guidelines for the use of antibiotics in acute upper respiratory tract infections. Am Fam Physician. 2006;74(6): $956-66$.

8. Botelho C, Correia AL, Silva AMC, Macedo AG, Silva COS. Fatores ambientais e hospitalizações em crianças menores de cinco anos com infecção respiratória aguda. Rep Public Health. 2003;19(6):1771-80.

9. Sih TM. Infectologia em otorrinopediatria: uso criterioso de antibióticos em infecções das vias aéreas superiores. Rio de Janeiro: Revinter; 2001. 